\title{
Savannah River Site Sample \& Analysis Plan for Clemson Technical Center Waste
}

by

T. Hagstrom

Westinghouse Savannah River Company

Savannah River Site

Aiken, South Carolina 29808

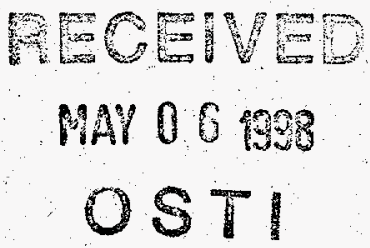

DASTRIBUTION OF THIS DOCUMENT IS UNLITED $\rho$

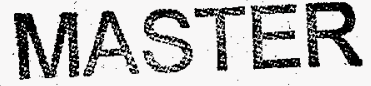

DOE Contract No. DE-AC09-96SR18500

This paper was prepared in connection with work done under the above contract number with the U.S. Department of Energy. By acceptance of this paper, the publisher and/or recipient acknowledges the U.S. Government's right to retain a nonexclusive, royalty-free license in and to any copyright covering this paper, along with the right to reproduce and to authorize others to reproduce all or part of the copyrighted paper. 


\section{DISCLAIMER}

This report was prepared as an account of work sponsored by an agency of the United States Government. Neither the United States Government nor any agency thereof, nor any of their employees, makes any warranty, express or implied, or assumes any legal liability or responsibility for the accuracy, completeness, or usefulness of any information, apparatus, product, or process disclosed, or represents that its use would not infringe privately owned rights. Reference herein to any specific commercial product, process, or service by trade name, trademark, manufacturer, or otherwise does not necessarily constitute or imply its endorsement, recommendation, or favoring by the United States Government or any agency thereof. The views and opinions of authors expressed herein do not necessarily state or reflect those of the United States Government or any agency thereof.

This report has been reproduced directly from the best available copy.

Available to DOE and DOE contractors from the Office of Scientific and Technical Information, P.O. Box 62, Oak Ridge, TN 37831; prices available from (615) 576-8401.

Available to the public from the National Technical Information Service, U.S. Department of Commerce, 5285 Port Royal Road, Springfield, VA 22161. 


\section{DISCLAIMER}

Portions of this document may be illegible in electronic image products. Images are produced from the best available original document. 


\title{
Savannah River Site \\ Sample and Analysis Plan \\ for Clemson Technical Center Waste (U)
}

April 1998

\author{
Prepared by \\ BNFL-SR \\ Aiken, SC 29808 \\ for the
}

U. S. DEPARTMENT OF ENERGY

Savannah River Operations Office

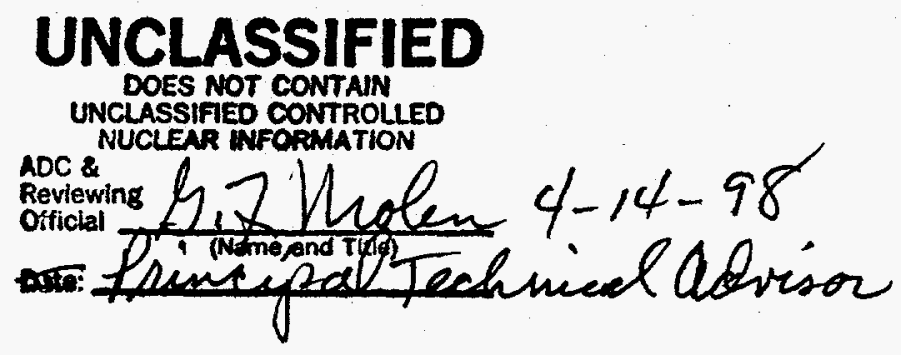




\section{SAMPLE PLAN APPROVAL}

Date

Solid Waste Division - Operations

Date

Solid Waste Division - Engineering

Date

Solid Waste Division - Quality Assurance 


\section{TABLE OF CONTENTS}

1.0

PURPOSE

4

2.0

OBJECTIVES

4

3.0 PCB CONTAMINATED LIQUIDS

4

3.1 Scope

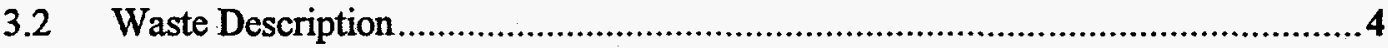

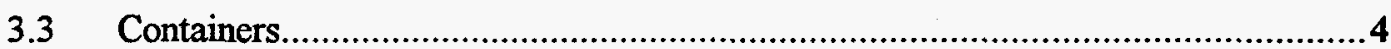

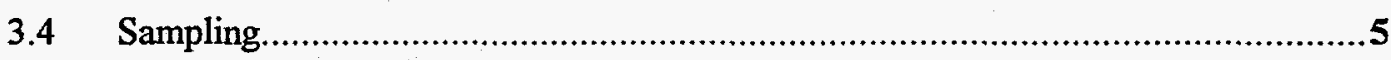

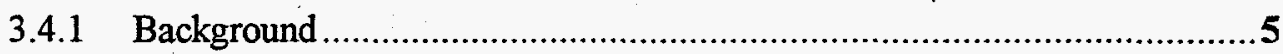

3.4.2 Sample Collection for Liquid Waste Forms ........................................5

3.4.3 Representative Samples ..............................................................5

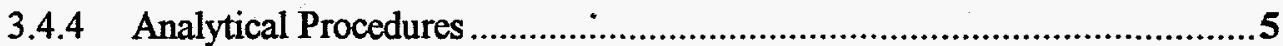

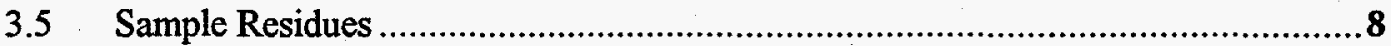

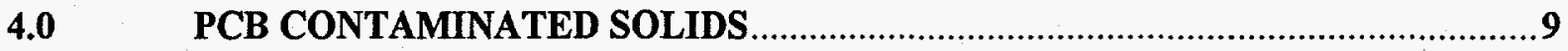

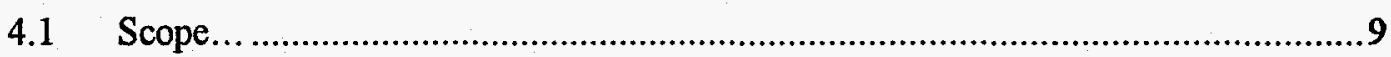

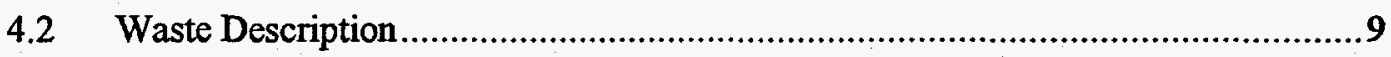

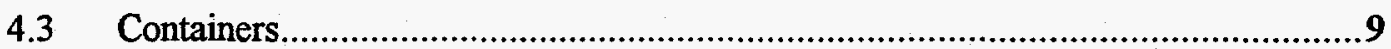

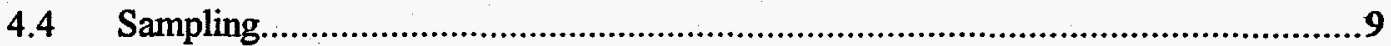

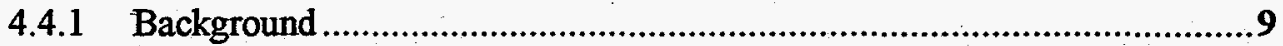

4.4.2 Sample Collection for Liquid Waste Forms ......................................9

4.4.3 Representative Samples ............................................................. 10

4.4.4 Analytical Procedures ................................................................12

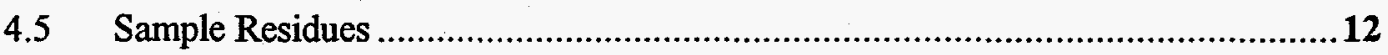

$5.0 \quad$ QUALITY ASSURANCE

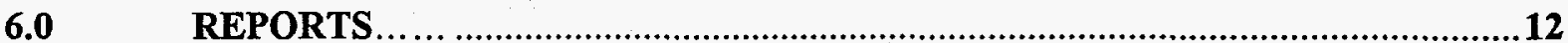

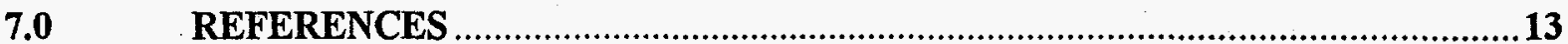




\section{ATTACHMENTS}

1 Sampling Container Contents - Liquid Waste

2 Sampling Container Contents - Solid Waste 


\section{Sampling/Analysis Plan for SRS Radioactive PCB Waste}

\subsection{PURPOSE}

The purpose of this sampling and analysis plan is to determine the chemical, physical and radiological properties of the SRS radioactive Polychlorinated Biphenyl (PCB) liquid waste stream, to verify that it conforms to Waste Acceptance Criteria of the Department of Energy (DOE) East Tennessee Technology Park (ETTP) Toxic Substance Control Act (TSCA) Incineration Facility.

\subsection{OBJECTIVES}

Waste being sent to the ETTP TSCA Incinerator for treatment must be sufficiently characterized to ensure that the waste stream meets the waste acceptance criteria to ensure proper handling, classification, and processing of incoming waste to meet the Waste Storage and Treatment Facility's Operating Permits.

All waste samples shall be collected and managed in accordance with EPA SW-846, "Test Methods for Evaluating Solid Waste, Physical/Chemical Methods" Current Edition.

\subsection{PCB CONTAMINATED LIQUIDS}

\subsection{Scope}

This sampling and analysis plan is limited to-WSRC container(s) of homogeneous or multiphasic radioactive $\mathrm{PCB}$ contaminated liquids generated in association with a treatability study at Clemson Technical Center (CTC) and currently stored at the WSRC Solid Waste Division Mixed Waste Storage Facility (MWSF).

\subsection{Waste Description}

The waste material referenced in this sampling and analysis plan are the WSRC radioactive PCB liquid wastes planned to be shipped to the K-25 TSCA Incinerator for treatment. These waste materials are stored in our Resource Conservation Recovery Act (RCRA) Mixed Storage Facility and consist primarily of heterogeneous liquids. The material within the container exhibits the RCRA hazardous waste characteristic for ignitability (D001), and is contaminated with RCRA F001 solvents, polychlorinated biphenyls, and radionuclides.

\subsection{Containers}

The SRS liquid wastes from the CTC study total approximately 51 gallons in volume and are currently stored in 4 containers, but will be consolidated into one U. S. Department of Transportation (DOT) approved container prior to sampling and shipment to ETTP. 


\subsection{Sampling}

\subsubsection{Background}

When the subject waste was generated at CTC, it was placed in buckets and in drums, which were overpacked prior to shipment to SRS. Prior to the sampling activities described herein, overpacks will be removed.

\subsubsection{Sample Collection for Liquid Waste Forms}

The following table summarizes the sample collection methods considered appropriate for the given waste forms. All methods listed below are described in detail in EPA SW-846, "Test Methods for Evaluating Solid Waste, Physical/Chemical Methods SW-846", the most current edition.

\section{PHYSICAL/CHEMICAL METHODS}

\section{Waste Form}

Oils, solvents, chemicalsdrum

or aqueous waste

Unknown liquids
Container Type

drum
Sampling Method

Coliwasa

\subsubsection{Representative Samples}

If the consolidated liquid waste consists of multiple layers/phases, the contents will be mixed using a circulatory pump or other appropriate device. A homogeneous sample will then be drawn. This sample will be sent to LMAS in Oak Ridge for characterization in conformance to the TSCA Incinerator WAC.

Immediately after sampling, the waste container(s) will be sealed by the WSRC generator personnel, and a Chain-of-Custody (COC) seal will be affixed to the container(s) with the identification number of the $\mathrm{COC}$ recorded on the waste analysis sheet (attachment $\mathrm{I}$ ). WSRC personnel will record the COC seals identification numbers in Section "J" of the Uniform Hazardous Waste Manifest. The manifest will be given to the waste trarporter. The transporter and WSRC generator personnel will check the COC seals on the waste storage containers and compare the identification numbers to the information recorded on the manifest. Both the WSRC generator and transporter personnel will sign and date the manifest before the shipment and transporter departs the Savannah River Site.

\subsubsection{Analytical Procedures}

Analytical methods and parameters for the liquid waste samples are indicated in Table 3-1 below. 
TABLE 3-1 Analytical Parameters/Methods

PARAMETER

Cyanide, Total

Elements by High Pressure Asher Prep

Thallium by EPA 7841 Furnace AA

Arsenic by EPA 7060 Furnace AA

Selenium by EPA 7740 Furnace AA

Lead by EPA 7421 Furnace AA

Mercury in Liquid Waste/Extracts/Waters

pH Electrometric Measurement

Total Suspended Solids

Total Solids

Ignitability (Plash Pt) Closed Cup

Total Petroleum Hydrocarbons

Volatile Organics by Purge-and-Trap GC/MS

Semi-Volatile Organics by GC/MS

Polychlorinated Biphenyls by GC

Gross Alpha/Beta Act. By 160060

Total Activity using LSC by 160063

Tc-99 Activity using LSC by 160063

Gamma Spectrometry by 160067

Isotopic Thorium act. By 160083

Isotopic Neptunium Act. By 160083

Isotopic Plutonium Act. By 160083

Isotopic Uranium Act. By 160083

\section{METHOD}

SW846 9010

SW846 6010A

SW846 7841

SW846 7060

SW846 7040

SW846 7421

SW846 7470

SW846 9040

EPA 160.21971

EPA 160.31971

SW846 1010

EPA 418.11978

SW846 8260

SW846 8270

SW846 8080

ASO ACD-160082

ASO ACD-160063

ASO ACD-160063

ASO ACD-160067

ASO ACD-160083

ASO ACD-160083

ASO ACD-160083

ASO ACD-160083 
Anions by IC (EPA 300.0)

Releasable H2S (SW846 Chapter 7/9030)

Releasable HCN (SW846 Chapter 7/9010)

Boiling Point, ASTM D1120

Gross Calorific Value (BTU) of Waste Samples

Percent Ash of Waste Samples

Corrosivity of Waste Samples

Density of Solid and Liquid Wastes

Specific Gravity

Fluoride (EPA 340.2) Ion Specific Electrode

Vapor Pressure, ACD-184107

Freezing Point (ASTM D1177) of Liquid Waste

Karl Fischer Reagent Moisture Analysis

Viscosity

Total Uranium and \% U-235 by TIMS - 9995

Phases in Waste

Isotopic Neptunium Act. By 160083 (DUP)

Isotopic Plutonium Act. By 160083 (DUP)

Total Uranium and \% U-235 by TIMS - 9995 (DUP)
EPA 300 Dec89

SW846 Ch.7, Sec. 7.3.

SW846 Ch.7, Sec. 7.3.

ASTM D1120-89

ASTM D3286-91

ASTM D482-87

SW846 1110

ASO ACD-182407

ASTM D287-82

EPA 340.21974

ASO ACD-184107

ASTM D1177-88

ASTM D1533-88

ASTM D2983-87

ASO Y/P65-8044

ASO ACD- 015000

ASO ACD-160083

ASO ACD-160083

ASO Y/P65-8044

Note: Uranium concentration, U-235 enrichment, Pu-238, Pu-239, Np-237 and U-233 shall be sampled according to the guidance below to establish a 95/95 confidence level of the waste stream to be accepted. Although one 55 gallon container of liquid represents the waste stream, multiple samples (three) will be independently taken and analyzed to provide confirmation that $95 \%$ confidence level is achieved. 


\section{Sampling/Container Requirements}

\begin{tabular}{|c|c|c|}
\hline Analysis & Volume & Bottle Type \\
\hline VOA & $2 \times 40 \mathrm{ml}$ & $\begin{array}{l}40 \mathrm{ml} \text { glass amber vial, zero headspace, } \\
\text { Teflon lined lid. }\end{array}$ \\
\hline PCB & $3 \times 1$ liter & glass, Teflon lined lid \\
\hline BNA & $3 \times 1$ liter & glass, Teflon lined lid \\
\hline Reactive Cyanide & $250 \mathrm{ml}$ & Plastic or glass \\
\hline Reactive Sulfide & $250 \mathrm{ml}$ & Plastic or glass \\
\hline TPH & 1 liter & Glass \\
\hline Metals & $100 \mathrm{ml}$ & Plastic or glass \\
\hline Radiochemistry & $2 \times 100 \mathrm{ml}$ & Plastic-or-glass \\
\hline
\end{tabular}

The following analyses will be performed on single 1 liter sample collected in a 1 liter glass or plastic bottle:

$\begin{array}{lll}\text { Vapor Pressure } & \text { Anions } & \text { Total Fluoride } \\ \text { Ash Content } & \text { Freezing Point } & \text { Boiling Point } \\ \text { Corrosivity } & \text { Karl Fischer Water } & \text { Specific Gravity } \\ \text { Density } & \text { Viscosity } & \text { Flash Point } \\ \text { pH } & \text { Heating Value (BTU) } & \text { Total Cyanide }\end{array}$

\subsection{Sample Residues}

The Oak Ridge Laboratory performing the analyses shall properly archive and/or disposition all sample residues remaining after completion of all requested WSRC analyses. 


\subsection{PCB CONTAMINATED SOLIDS}

\subsection{Scope}

This sampling and analysis plan is limited to WSRC container(s) of heterogeneous radioactive PCB contaminated solid material(s) stored at the WSRC Solid Waste Division Mixed Storage Facility (645-2N).

\subsection{Waste Description}

The waste material referenced in this sampling and analysis plan are the WSRC radioactive PCB solid wastes which will be segregated per the requirements of the TSCAI WAC into incinerable and non-incinerable categories. Following sampling, characterization and TSCAI approval, the incinerable solids will be shipped to the K-25 TSCA Incinerator for treatment. These waste materials are stored in our Resource Conservation Recovery Act (RCRA) Mixed Storage Facility and consist primarily of heterogeneous solids. The material within the containers is contaminated with polychlorinated biphenyls, and radionuclides. The qualifying incinerable waste to be sent to TSCAI includes but is not limited to the following list:

empty plastic bottles

plastic sheeting

cardboard

spill pillows

oil dry

air filter media (removed from frame)

vacuum hose

paper rags

\author{
plastic trays \\ personal protective equipment \\ plastic bags \\ leather work gloves \\ plastic buckets \\ HEPA filter cartridges \\ garden hose
}

\subsection{Containers}

Incinerable SRS PCB/radioactive solid wastes are stored and will be shipped offsite in DOT approved containers.

\subsection{Sampling}

\subsubsection{Background}

SRS personnel will sort and segregate the solid waste into incinerable and non-incinerable units, after which they will draw samples from the incinerable wastes. The samples will be sent to an offsite lab for radiological, physical and chemical characterization analyses.

\subsubsection{Sample Collection for Solid Waste Forms}

The following table summarizes the sample collection methods considered appropriate for the given waste forms. All methods listed below are described in detail in EPA SW-846, "Test Methods for Evaluating Solid Waste, Physical/Chemical Methods", the most current edition. 


\section{PHYSICAL/CHEMICAL METHODS}

Waste Form Container Type Sampling Method

Solids Drum Auger grab (hand, tongs, tweezers), scoop, wipe sample

\subsubsection{Sample Management and Waste Custody}

Immediately after sampling, the waste container(s) will be sealed by the WSRC generator personnel, and a Chain-of-Custody (COC) seal will be affixed to the container(s) with the identification number of the COC recorded on the waste analysis sheet (see attachment $\mathbf{I}$ ). The chain-of-custody must not be broken in order to maintain the integrity of the fully characterized waste for later shipment to the TSCA Incinerator. WSRC personnel must record the COC seals identification numbers in Section "J" of the Uniform Hazardous Waste Manifest. The manifest will be given to the waste tranporter. The transporter and WSRC generator personnel will check the $\mathrm{COC}$ seals on the waste storage containers and compare the identification numbers to the information recorded on the manifest. Both the WSRC * generator and transporter personnel will sign and date the manifest before the shipment and transporter departs the Savannah River Site.

\subsubsection{Analytical Procedures}

Analytical methods and parameters for the solid waste samples are indicated in Table 4-1 below.

\section{TABLE 4-1 Analytical Parameters/Methods}

\section{PARAMETER}

Cyanide

Reactive Cyanide

Reactive Sulfide

Metals: except $\mathrm{Tl}, \mathrm{Se}, \mathrm{As}, \mathrm{Hg}$

Thallium by EPA 7841 Furnace AA

Arsenic by EPA 7060 Furnace AA

Selenium by EPA 7740 Furnace AA

Mercury

Ignitability (Flash Pt) Closed Cup

\section{METHOD}

EPA 335.2

EPA 9010

EPA 9030

SW-846 6010

SW-846 7841

SW846 7060, 6010

SW846 7740

SW846 7470, 7471

SW846 1010 
PARAMETER

Total Petroleum Hydrocarbons

Semi-Volatile Organics by GC/MS

Pesticides/PCBs

Gross Alpha/Beta

Total Activity

Gross Calorific Value (BTU) of Waste Samples

Ash Content

Corrosivity of Waste Samples

Bulk Density

Total Fluorides

Moisture

Total Uranium and \% U-235 by TIMS - 9995

Herbicides

Volatile Organics

Chloride

Sulfur

U-alpha

U-235 (gamma)

U-235 Wt \%/ Total Uranium
METHOD

Per K-25 Lab methodology

SW846 8270B, 8250A

SW846 8080A

Per K-25 Lab methodology

Liquid Scintillation Counting

ASTM D3286-91

ASTM D482-80

SW846 9045

ASTM D-5057

ASTM D-3761, EPA 340.2

ASTM D-2216, ASTM D-2974

ASO Y/P65-8044

SW846 8150B,8151

SW846 8240, 8240A, 8240B, $8260,8260 \mathrm{~A}$

ASTM D-376, EPAं 300.0

ASTM D-376, EPA 300.0

Alpha spectroscopy

Gamma Spectroscopy

Thermal Ionization Mass Spec.

Note: Uranium concentration, U-235 enrichment, $\mathrm{Pu}-238, \mathrm{Pu}-239, \mathrm{~Np}-237$ and U-233 shall be sampled to establish a 95/95 confidence level of the waste stream to be accepted:

The heterogeneous incinerable solid waste container population will be randomly divided into three equally sized subgroups. Each container matrix will be sampled and triplicate composite samples formed for each of the subgroups. Each sample taken will be independent in order to achieve a confidence level of $95 \%$. 


\subsection{Sample Residues}

The Oak Ridge Laboratory performing the analyses shall properly archive and/or disposition all sample residues remaining after completion of all requested WSRC analyses.

\subsection{QUALITY ASSURANCE}

Accuracy and precision shall be determined and assessed through the use of quality control samples including blanks and duplicates.

\section{Data Quality Objectives}

\section{Precision}

Precision is a quantitative measure of data quality that refers to the reproducibility or degree among replicate or duplicate measurements of a parameter. Data precision is a function of field sampling precision and laboratory analytical precision. Precision will be determined by calculating the relative percent difference (RPD) between a sample and its duplicate.

\section{$\underline{\text { Accuracy }}$}

Accuracy is a quantitative measure of data quality that refers to the degree of difference between measured or calculated values of a parameter and the true value of that parameter. The closer the measurement is to the true value, the more accurate the measurement. Accuracy will be controlled primarily by the analytical laboratory through the preparation and analysis of laboratory quality control samples, including matrix spikes and standard reference materials.

\section{Representativeness}

Representativeness is a quantitative measure of the degree to which the sampling effort achieves accuracy and precision. Representativeness of samples and data will be ensured by adhering to the SW 846 sampling protocols and procedures referenced herein.

\section{Comparability}

Comparability is a qualitative measure that expresses the confidence with which one data set can be compared to another. It will be achieved by adhering to specified field sampling procedures. The same analytical laboratory will perform the specified analyses for all samples using the standard methods detailed in this plan.

\subsection{REPORTS}

All analytical data, including summaries, data validation and $\mathrm{COC}$ copies, will be made available to WSRC by the offsite analytical laboratory within 30 days of the initial receipt of the samples. 


\subsection{REFERENCES}

EPA SW-846, "Test Methods for Evaluating Solid Waste, Physical/Chemical Methods, Current Edition".

40 CFR Part 261, Appendix I, “Representative Sampling Methods".

WSRC ECM 6.15 "Waste Sampling Methods Under Resource Conservation and Recovery Act”, (Rev 2, April 1, 1996)

WSRC ECM 6.26 “Sampling Containerized Solids”, (Rev 0, December 4, 1995) 


\section{ATTACHMENTS}




\section{Attachment 1 \\ Sampling Container Contents - Liquid Waste}

Prior to initiating work in the hut, verify Rad Con acceptance.

1.0 Sample Collection Procedures for Volatile Organics, Semi-Volatiles, and PCBs.

1.1 Place all appropriate sampling equipment (coliwasa, mucksucker, bottles, bags, etc.) into the hut. All sample bottles should be labeled and segregated prior to sampling container(s).

1.2 Remove the bung or container lid and place on a large plastic bag to minimize the spread of contamination. Sleeve the coliwasa, if appropriate, to minimize the spread of contamination.

1.3 Collect a discrete grab sample by inserting the coliwasa or mucksucker to the bottom of the container to ensure a representative sample. If the container(s) contain sediments care must be taken to accurately represent the sediment layers, and this can be achieved by hand or mechanical mixing to put the sediments back in to solution before the sample(s) are taken.

1.4 Rad Con personnel will probe the sample material for activity levels. If the activity levels are below the job specific RWP's activity and/or dose suspension guidelines, dispense the sample material into the specified sample container. If the activity levels are above the suspension limits, transfer the sample material back into the container and replace the container lid.

1.4 If possible, ensure the container(s) are filled to the top to minimize volatile loss.

1.5 Take the sample container and check that a Teflon liner is present in the cap. Secure the cap tightly.

1.6 Record appropriate sample data on the sample log sheets (phases, color, solids, and other observations).

1.7 Place the samples collected into a clear plastic bag and set aside in the hut. Rad Con personnel will survey and tag each plastic bags containing samples for removal from the contamination area when all sampling is complete.

1.8 After all samples are removed from the area, package the sample containers for transport and shipping. Samples should be cooled to $4^{\circ} \mathrm{C}$ as soon as possible.

1.9 Replace the drum lid and any disposable solid contaminated equipment (gloves, plastic sheets, swipes, sample residue, etc.) should be placed in plastic bags for disposal back into the drum. 
2.0 Liquid Sample Collection Procedures for Metals, , Releasable Cyanide, Releasable Sulfide, Isotopic Thorium Activity, Isotopic Plutonium Activity, Isotopic Neptunium Activity, Isotopic Uranium Activity, Gamma Spectrometry, Total Uranium Activity and $\% \mathrm{U}-235$.

2.1 Collect a discrete grab sample using the coliwasa. Rad Con personnel will probe the sample material for activity levels. If the activity levels are below the job specific RWP's suspension guidelines, dispense the sample material into the specified sample container. If the activity levels are above the suspension limits, transfer the sample material back into the container and replace the container lid.

2.2 Collect additional grab samples and composite the discrete samples into the designated sample container until the specified sample volume is obtained for each of the analytical parameters (see page 1).

2.3 Two duplicate samples shall be taken for the Isotopic Plutonium Activity, Isotopic Neptunium Activity, and Total Uranium Activity and \% U-235 analyses.

$2.4 \quad$ Repeat steps 1.5-1.7.

3.0 Liquid Sample Collection Procedures for $\mathrm{pH}$, Total Suspended Solids, Ignitability, Anions, Boiling Point, Freezing Point, BTU/Lb., Percent Ash Content, Corrosivity, Density, Specific Gravity, Fluoride vapor pressure, Karl Fischer Reagent Moisture Analysis, and Phases.

3.1 Collect discrete grab samples using the coliwasa. Take additional grab samples as required and composite the discrete grab samples into the designated sample container until the 1 liter sample volume is obtained.

3.2 A duplicate $1 \mathrm{~L}$ sample shall be taken.

3.3 Take the sample container and check that a Teflon liner is present in the cap. Secure the cap tightly.

3.4 Replace the container lid and any disposable solid contaminated equipment (gloves, plastic sheets, etc.) should be placed in plastic bags for temporary storage or disposal by Şolid Waste Operations personnel.

3.5 After the samples are cleared radiologically, package the sample containers for offsite shipment. Samples should be cooled to $4^{\circ} \mathrm{C}$ as soon as possible, if applicable.

3.5 Seal each of the waste containers with a tamper indicating device (TID) and record the identification number on the chain-of-custody form. 


\section{Attachment 2}

\section{Sorting and Sampling Container Contents - Solid Waste}

\section{Pre-sorting Container Contents - Solid material}

The following inventory was generated at CTC during decontamination and demobilization activities. It is summarized here to assist with the sorting/segregation and subsequent sampling of solid wastes prior to shipment to TSCAI. If the solid waste form(s) consist of multiple matrices, then each matrix shall be sorted, segregated, after which each incinerable component shall be independently sampled and analyzed.

\section{Inventory}

Container \#1 : Type - 55 gallon open top placed in 85 gallon overpack.

Waste Description - Larger laboratory waste pieces including plastic sample bottle, plastic trays, plastic sheeting, and Personal Protective Equipment (PPE).

Container 2 : Type - 55 gallon open top placed in 85 gallon overpack

Waste Description - Analytical samples of decon sand, laboratory glassware, plastic bottles, and PPE.

Container 3 :Type - 55 gallon open top with liner placed into 85 gallon overpack.

Waste Description: 2 Capacitors, 1 transformer, plastic bucket, oil soaked cardboard in plastic bag.

Container 4: Type - 55 gallon open top with liner placed into 85 gallon overpack.

Waste Description: Plastic 5 gallon drum, cut up sections of white garden hose, shredded material including rope, plastic bags, cardboard and PPE.

Container 5:Type -55 gallon open top with liner placed into 85 gallon overpack.

Waste Description: None

Container 6:Type - 55 gallon open top with liner placed into 85 gallon overpack.

Waste Description : 3 Capacitors, transformers, fluorescent light ballasts, miscellaneous electrical equipment and wire.

Container 7:Type -55 gallon open top placed into 85 gallon overpack.

Waste Description : Metal mop bucket, metal mop wringer, hand shears, metal dust pan, 2 bags of Vac Trax decon sand.

Container 8:Type - 55 gallon open top with liner (no liner top included) placed into 85 gallon overpack.

Waste Description - Original SRS material including shredded and non-shredded cardboard, plastic, spill pillows, nitrile gloves, PPE, paper oil soaked cardboard, shredded leather work gloves.

Container 9:Type - 55 gallon open top placed into 85 gallon overpack. 
Waste Description - Spill pillows, paper, cardboard, shredded plastic, oil dry, loose oil dry in bottom of drum.

Container 10 : Type - 85 gallon open top placed into 110 gallon overpack. Waste Description - 5 plastic lab tubs, (2) plastic 5 gallon buckets, PPE.

Container 12: Type - 85 gallon open top.

Waste Description - 1 bag of GEL contact debris, glass plastic, paper, 1 bag of empty sample bottles, 110 gallon DOT can containing filter media in a plastic bag (high alpha activity, CTC did not sample), 15 gallon DOT can containing HEPA filter cartridges and associated salts in a plastic bag.

Container 13 : Type - 85 gallon open top.

Waste Description - 6 bags of GEL analytical solid residues (including vermiculite), 1 bag of decontamination materials (PPE, plastic gloves.

Container 18 : Type - 5 gallon HPE bucket

Waste Description - Solid decontamination residues; paper rags contaminated with kerosene.

Container \# 95080 : Type - 55 gallon open top placed in a 85 gallon overpack

Waste Description - plastic sample containers, porous laboratory materials from original characterization, vacuum hose, zip lock bags with swipes.

\section{Sorting Solid Waste}

PCB/radioactive solids from the CTC study will be sorted into wastes that are acceptable for burning at TSCAI and those which are not. The sorting process will be designed to minimize unnecessary contamination of additional containers, PPE and other job control waste. Sampling activities will be integrated with sorting, to avoid reopening of containers.

\section{Sampling Solid Waste}

Deliberately sample the most contaminated objects, if they are evident visually. This biased approach will yield an estimate of the maximum contamination level for each material type.

The approach taken is the most conservative, i.e. it targets the most-contaminated items. If for any reason the drum must be resampled, the second sample will probably contain less of the hazardous constituent than the first sample and will be less accurate estimate of the maximum contamination present.

Soft material, clothing, paper, rags, plastic bags, plastic sheets, shall be sampled in one of several ways:

- Cut out pieces from each article using scissors or shears until enough material is obtained for a sample.

- Punch holes in the material using something similar to a large diameter paper punch. 
- Place the material back into the containers. Obtain a core sample using a hand-held coring device.

Wood Material shall be sampled as follows:

- If the wood is in chip form, sampling personnel remove the necessary quantity to perform the required analyses.

- If the wood is in large pieces - boards or construction timber, for example - locate an area of visible contamination and sample that section.

\section{Equipment Decontamination/ Disposal}

- Any disposable solid contaminated equipment (plastic sheets, scoops, etc.) will be placed in plastic bags for temporary storage and disposed of by the customer.

\section{Sampling Procedures}

\section{Prior to initiating work in the hut, verify Rad Con acceptance.}

\subsection{Sample Collection Procedures for Volatile Organics and PCBs.}

1.1 Place all appropriate sampling equipment (trier, auger, scoops, bags, etc.) into the hut. All sample bottles should be labeled and segregated prior to sampling container(s).

1.2 Remove the container lid and place on a large plastic bag to minimize the spread of contamination.

1.3 Collect discrete randomly selected grab samples for each container as specified on page of Attachment 1. Rad Con personnel will probe the sample material for activity levels. If the activity levels are below the job specific RWP's suspension guidelines, place the sample material into the specified sample container. If the activity levels are above the suspension limits, transfer the sample material back into the container and replace the container lid.

1.4 Ensure the container(s) are filled to the top to minimize volatile loss.

1.5 Open the sample container and check that a Teflon liner is present in the cap. Secure the cap tightly.

1.6 Record appropriate sample data on the sample log sheets (color, solids, and other observations). 
1.7 Place the samples collected into a clear plastic bag and set aside in the hut. Rad Con personnel will survey and tag each plastic bags containing samples for removal from the contamination area when all sampling is complete.

1.8 After all samples are removed from the area, package the sample containers for transport and shipping. Samples should be cooled to $4^{\circ} \mathrm{C}$ as soon as possible.

1.9 Replace the drum lid and any disposable solid contaminated equipment (gloves, plastic sheets, swipes, sample residue, etc.) should be placed in plastic bags for disposal back into the drum.

2.0 Sample Collection Procedures for Metals, Semi-Volatiles, Isotopic Thorium Activity, Isotopic Plutonium Activity, Isotopic Neptunium Activity, Isotopic Uranium Activity, Gamma Spectrometry, Total Uranium Activity and \% U-235.

2.1 Collect a discrete grab sample using the coliwasa. Rad Con personnel will probe the sample material for activity levels. If the activity levels are below the job specific RWP's suspension guidelines, dispense the sample material into the specified sample container. If the activity levels are above the suspension limits, transfer the sample material back into the container and replace the container lid.

2.2 Collect additional grab samples, if required, and composite the discrete grab samples into the designated sample container until the specified sample volume is obtained for each of the analytical parameters (see page 1).

2.3 Duplicate $250 \mathrm{ml}$ samples shall be taken for the Isotopic Plutonium Activity, Isotopic Neptunium Activity, and Total Uranium Activity and \% U-235 analyses.

$2.4 \quad$ Repeat steps 1.5-1.7.

3.0 Solid Sample Collection Procedures for Ignitability, BTU/Lb., Percent Ash Content, Corrosivity, Bulk Density.

3.1 Collect discrete grab samples using the coliwasa. Take additional grab samples as required and composite the discrete grab samples into the designated sample container until the 1 liter sample volume is obtained.

3.2 A duplicate $1 \mathrm{~L}$ sample shall be taken.

3.3 Take the sample container and check that a Teflon liner is present in the cap. Secure the cap tightly.

3.4 Replace the container lid and any disposable solid contaminated equipment (gloves, plastic sheets, etc.) should be placed in plastic bags for temporary storage or disposal by Solid Waste Operations personnel. 
3.5 After the samples are cleared radiologically, package the sample containers for offsite shipment. Samples should be cooled to $4^{\circ} \mathrm{C}$ as soon as possible, if applicable.

3.6 Seal each of the waste containers with a tamper indicating device (TID) and record the identification number on the chain-of-custody. 